\title{
Clinical and Ultrasonographic Aspects of Benign and Malignant Mammary Tumors in Female Dogs
}

\author{
Paula Elisa Brandão Guedes ${ }^{1}$, Hannah Bandeira Thame Daniel ${ }^{2}$, Kátia Moema Oliveira Rosa Sampaio ${ }^{3}$, \\ Elizângela Barboza da Silva ${ }^{3}$, Manoel Luiz Ferreira ${ }^{3}$, Mário Sérgio Lima de Lavor ${ }^{3}$, \\ Rosana Maria de Oliveira Clark ${ }^{3}$, Amauri Arias Wenceslau ${ }^{3}$, Roueda Abou Said ${ }^{3}$ \& Fabiana Lessa Silva ${ }^{3}$
}

\begin{abstract}
Background: Mammary neoplasms in dogs are commonly observed in veterinary clinical routine, most of which being malignant. Hormonal stimulation, endogenous or exogenous, may possibly influence its development. In addition to clinical evaluation, ultrasound analysis can provide information about the characteristics of breast lumps. The association between clinical-epidemiological and pathological data is important for diagnosis. Therefore, given the importance of this pathology for the health of affected dogs, we aimed to evaluate the clinical and ultrasound alterations, along with the factors associated with the development of benign and malignant mammary neoplasms in female dogs.

Materials, Methods \& Results: We examined 47 samples from the mammary tumors of 35 female dogs at the Small Animal Clinic of the Veterinary Hospital (HV) of the Santa Cruz State University (UESC). The dogs underwent a complete clinical examination, with clinical staging, via TNM classification, followed by hematological, biochemical, radiological and ultrasound, abdominal, and breast exams. Breast ultrasound examination was used to evaluate the shape parameters such as, limits, margins or contour, ecotexture, echogenicity, hyperechoic halo, posterior acoustic shading, surrounding changes, and nodule components. These criteria were associated with the histopathological classification of neoplasms. Epidemiological data was studied through an adapted questionnaire containing information on risk factors associated with breast cancer. The same questionnaire was applied to tutors of 19, age-matched, female dogs with no history of breast cancer. The results revealed that most female dogs with neoplasia were over eight years of age, with no specific breed and were not castrated, and $31.4 \%$ of them had already been administered with contraceptives during the reproductive period. Ovariohysterectomy acted as a protective factor (OR 0.06) to the development of breast tumors, while contraceptive use was considered as a risk factor (OR 6.99). The average time reported between tumor perception and clinical care was 13.2 months. The caudal and inguinal abdominal breasts were the most affected. Among the samples evaluated, $76.6 \%$ were malignant, with mixed tumor carcinoma being the most frequent type and $69.4 \%$ graded in grade I. Nodules classified as malignant showed the largest diameter $(P<0.05)$. Breast ultrasound results revealed that tumors with heterogeneous echotextures and mixed components were associated with malignancy $(P<0.05)$.

Discussion: The fact that the average age of female dogs with breast cancer was over eight years of age corroborates the literature. Considering that a greater age would mean a longer exposure to the carcinogenic initiators responsible for mutations, and to promoters, such as hormonal changes. Contraceptives increase the risk of breast lumps, while reduce that of ovariohysterectomy, in female dogs, even when performed after the second heat. The size of the nodules and ultrasound criteria related to echotexture and the type of component of the neoplasia may be used as prognostic parameters of female breast nodules. Additionally, most nodules evaluated in this study were malignant (mixed tumor carcinoma was the most common subtype), possibly due to the owners' delay in seeking veterinary care after tumor observation. Although malignant, most nodules presented with a low histopathological grading.
\end{abstract}

Keywords: breast tumor, Canis familiaris, histopathology, prognosis, ultrasound.

DOI: $10.22456 / 1679-9216.101276$ 


\section{INTRODUCTION}

There has been an increase in the incidence of canine neoplasms, with the mammary tumor being the most frequent type in female dogs [5]. In Brazil, data show that over $90 \%$ of cases are malignant [28]. Hormonal stimulation, endogenous or exogenous, is thought to exert influence on its development. Endogenous hormonal factors include changes that occur during the estrus cycle [7] and pseudocyesis [21,24]. The exogenous influence is the use of hormonal therapy for contraceptive purposes [16,21].

History and macroscopic presentation of the tumor suggests the diagnosis of breast cancer. However, definitive diagnosis should be established by histopathological analysis [5]. The association between clinical-epidemiological and pathological data is important for diagnosis and may elaborate on the biological behavior of neoplasms [10,14,19,26,30]. Therefore, it is imperative to recognize the parameters with a prognostic value in clinical practice, as it facilitates the determination of the most appropriate therapy for each patient.

Ultrasonography is a great method to evaluate the characteristics of non-invasive and viable breast tumors. Node size, boundaries, margins, echotexture, echogenicity, formation of posterior acoustic shading, and depth/width ratio were some of the parameters evaluated. Some of these may be used as prognostic factors, associated with the biological behavior of neoplasms $[10,14,19,26,30]$.

This study aimed to evaluate the association between epidemiological, clinical, ultrasound, and pathological factors of benign and malignant mammary neoplasms in female dogs.

\section{MATERIALS \& METHODS}

\section{Animals}

The study was approved by the Animal Use Ethics Committee (CEUA-UESC), under protocol number 003/2015. The tutors of the animals included in this study were informed about the proposed methodology and objectives and signed an informed consent, allowing the participation and use of animal data.

The study included 47 samples from 35 adult female dogs of varying weight and race, who were seen at the Small Animal Clinic of the Veterinary Hospital
(HV) of the Santa Cruz State University (UESC), with suspected breast cancer.

\section{Physical examination}

Anamnesis and physical examination were performed, including palpation of the breasts and lymph nodes, as well as the measurement of the breast nodule (s) with the aid of the caliper to obtain the tumor diameter. In addition, other macroscopic characteristics of the nodule ( $\mathrm{s}$ ) were also evaluated, such as consistency, adherence to adjacent tissues and ulceration. After measuring the breast lump (s) and investigating the presence of metastases in distant lymph nodes or organs, clinical staging was established using the TNM classification [22].

\section{Laboratorial tests}

As a complementary evaluation, we performed hematological and biochemical exams, along with cardiological evaluation, electrocardiogram (ECAFIX electrocardiograph), digital radiographic examination (FUGIFILM) of the thoracic cavity in the left ventral and dorsal positions, and ultrasound abdominal and breast examination using the ULTRA VISION FLIP VET and linear transducer, with a frequency of 7.5 MHz. During the ultrasound examination of the breasts the following parameters of all breast nodules were evaluated: shape (elongated, rounded, ovoid or amorphous); boundaries (well-defined, partially defined or inaccurate/unclear); margins or contour (regular, partially regular or irregular); echotexture (homogeneous or heterogeneous); echogenicity (anechoic, hypoechoic, isoechoic, hyperechoic or mixed); hyperechoic halo; posterior acoustic shading (echo transmission present or absent); surrounding changes and nodule components (solid, liquid or mixed), according to Calas et al. [2]. The characteristics of the parietal lymph nodes were also evaluated.

\section{Surgical and histopathological procedures}

The female dogs clinically capable of undergoing anesthetic and surgical procedures were referred to undergo excision of the nodule(s) and partial or total mastectomy, depending on the extent of the neoplasia, while collecting the histopathology samples. Three of the samples included in the study were obtained immediately after euthanizing one of the female dogs, owing to the severity of her clinical condition, as a 
consequence of pulmonary metastasis, confirmed by radiographic examination.

Tissue samples were stored in a vial containing $10 \%$ buffered formaldehyde, where they remained for 24-48 h for proper fixation, with further processing using the conventional histological technique for paraffin embedding [23]. They were subsequently sectioned in a microtome to obtain 4-5 $\mu \mathrm{m}$ thick sections for histological slides, which were stained by the routine hematoxylin-eosin (HE) method for subsequent microscopic evaluation, diagnosis, classification and histopathological grading of tumors [13].

Epidemiological data was acquired via a questionnaire, adapted from Cassali et al. [5], containing information about risk factors associated with breast neoplasms. The same questionnaire was provided to the tutors of 19, age-matched, female dogs with no history of breast cancer.

\section{Statistical analysis}

To analyze the nonparametric parameters, clinical, ultrasonographic and histopathological findings of dogs with breast cancer, the Chi-Square and Fisher tests were used using the Open Epi statistical program, considering the significance level of $5 \%$.

\section{RESULTS}

This study included 35 female dogs, aged between two and 15 years, average of 9.7 years, with $85.7 \%$ of the dogs, eight years old or older. Table 1 includes the epidemiological data of female dogs treated with breast cancer, with healthy dogs in a control group. Regarding reproductive history, it was observed that ovariohysterectomy (OSH) was a protective factor (OR 0.06), while contraceptive was a risk factor (6.99), with a level of significance level of $95 \%$ (Table 2).

Table 1. Variables evaluated as risk factors for dogs with mammary neoplasms treated at HV-UESC and healthy dogs included in the study.

\begin{tabular}{|c|c|c|}
\hline & $\begin{array}{l}\text { Female dogs with mammary neoplasms } \\
\qquad \mathrm{N}=35\end{array}$ & $\begin{array}{l}\text { Healthy dogs } \\
\qquad \mathrm{N}=19\end{array}$ \\
\hline \multicolumn{3}{|l|}{ Breed } \\
\hline Non-defined race & $17(48.6 \%)$ & $4(21.1 \%)$ \\
\hline Pinscher & $3(8.6 \%)$ & $2(10.5 \%)$ \\
\hline Rottweiler & $3(8.6 \%)$ & 0 \\
\hline Poodle & $2(5.7)$ & $4(21.1 \%)$ \\
\hline Boxer & $2(5.7)$ & 0 \\
\hline Fox Paulistinha & $1(2.9 \%)$ & $1(5.3 \%)$ \\
\hline Labrador & $1(2.9 \%)$ & $2(10.5 \%)$ \\
\hline Argentine Dog & $1(2.9 \%)$ & 0 \\
\hline Lhasa Apso & $1(2.9 \%)$ & $2(10.5 \%)$ \\
\hline Dachshund & $1(2.9 \%)$ & 0 \\
\hline Dalmatian & $1(2.9 \%)$ & 0 \\
\hline Cocker Spaniel & $1(2.9 \%)$ & 0 \\
\hline German Shepherd & $1(2.9 \%)$ & 0 \\
\hline Schnauzer & 0 & $2(10.5 \%)$ \\
\hline Golden Retriever & 0 & $1(5.3 \%)$ \\
\hline Shih Tzu & 0 & $1(5.3 \%)$ \\
\hline \multicolumn{3}{|l|}{ Ovarian hysterectomy } \\
\hline Yes & $05(14.3 \%)$ & $14(73.7 \%)$ \\
\hline No & $30(85.7 \%)$ & $05(26.3 \%)$ \\
\hline \multicolumn{3}{|l|}{ Pseudocyesis } \\
\hline Yes & $13(37.1 \%)$ & $06(31.6 \%)$ \\
\hline No & $22(62.9 \%)$ & $13(68.4 \%)$ \\
\hline \multicolumn{3}{|l|}{ Contraceptive use } \\
\hline Yes & $10(28.6 \%)$ & $01(5.3 \%)$ \\
\hline No & $25(71.4 \%)$ & $18(94.7 \%)$ \\
\hline
\end{tabular}


P.E.B. Guedes, H.B.T. Daniel, K.M.O.R. Sampaio, et al. 2020. Clinical and Ultrasonographic Aspects of Benign and Malignant Mammary Tumors in Female Dogs.

Acta Scientiae Veterinariae. 48: 1723.

Table 2. Association between mammary neoplasms in female dogs and the variables non-defined race (SRD), ovarian hysterectomy (OSH), pseudocyesis, and contraceptive use.

\begin{tabular}{|c|c|c|c|c|c|c|c|}
\hline Variable & & $\mathrm{N}$ & $\begin{array}{c}\text { Female dogs with mammary } \\
\text { neoplasms }\end{array}$ & Incidence & $\begin{array}{l}\text { Odds } \\
\text { Ration }\end{array}$ & $\begin{array}{c}\text { Confidence } \\
\text { interval (95\%) }\end{array}$ & $P$ value \\
\hline \multirow{2}{*}{ SRD } & Yes & 21 & 17 & $81.00 \%$ & 3.09 & $0.88-12.78$ & 0.07 \\
\hline & No & 33 & 18 & $54.50 \%$ & 1 & & \\
\hline \multirow{2}{*}{ OSH } & Yes & 19 & 05 & $26.30 \%$ & 0.06 & $0.01-0.25$ & $0.00001 * *$ \\
\hline & No & 35 & 30 & $85.70 \%$ & 1 & & \\
\hline \multirow{2}{*}{ Pseudocyesis } & Yes & 19 & 13 & $68.40 \%$ & 1.27 & $0.38-4.45$ & 0.68 \\
\hline & No & 35 & 22 & $62.90 \%$ & 1 & & \\
\hline \multirow{2}{*}{ Contraceptive use } & Yes & 11 & 10 & $90.90 \%$ & 6.99 & $1.03-165.70$ & $0.04 *$ \\
\hline & No & 43 & 25 & $58.10 \%$ & 1 & & \\
\hline
\end{tabular}

Chi-Square; Fisher tests. * $(P<0.05) ; * *(P<0.01)$.

Among the 35 female dogs, nine presented with more than one nodule, resulting in 47 samples of neoplastic tissue. Among these, 11 (23.4\%) were classified microscopically as benign and $36(76.6 \%)$ as malignant. Among the benign, six (54.5\%) were papillomas, three $(27.3 \%$ ) adenomas, and two (18.2\%) benign mixed tumors. In relation to the malignant ones, $22(61.1 \%)$ were carcinomas in mixed tumors, $12(33.3 \%)$ simple carcinomas (tubular and papillary), one $(2.8 \%)$ pleomorphic carcinoma, and one (2.8\%) malignant adenomyopithelioma (Figures 1, 2 \& 3). Regarding the histopathological grading of the 36 carcinomas, 25 (69.4\%) were grade I, 11 (30.6\%) grade II, and none grade III.

Here, the reported time between tutors' perception of the tumor and referral to clinical care ranged from one to 60 months, with an average of 13.2 months, and four owners were unable to provide this information.

Physical examination revealed that the most affected breasts were caudal abdominal (21/47 - 44.7\%), followed by inguinal (15/47 - 31,9\%), cranial abdominal (7/47 - 14.9\%), and caudal thoracic (four / 47 - 8.5\%).

Regional lymphadenomegaly was present in 16 (45.7\%) female dogs, and eight (50\%) of the enlarged lymph nodes corresponded to the draining of affected breasts. However, none of the removed lymph nodes presented with neoplastic cells during the histopathological evaluation.

Clinical staging by the TNM system revealed that among the 29 female dogs with minimum one malignant neoplasia, nine (31.0\%) were in stage I, six
(20.7\%) in stage II, 13 (44.8\%) in III, and one in V $(3.4 \%)$. The animal demonstrating stage $\mathrm{V}$ was euthanized due to pulmonary metastases.

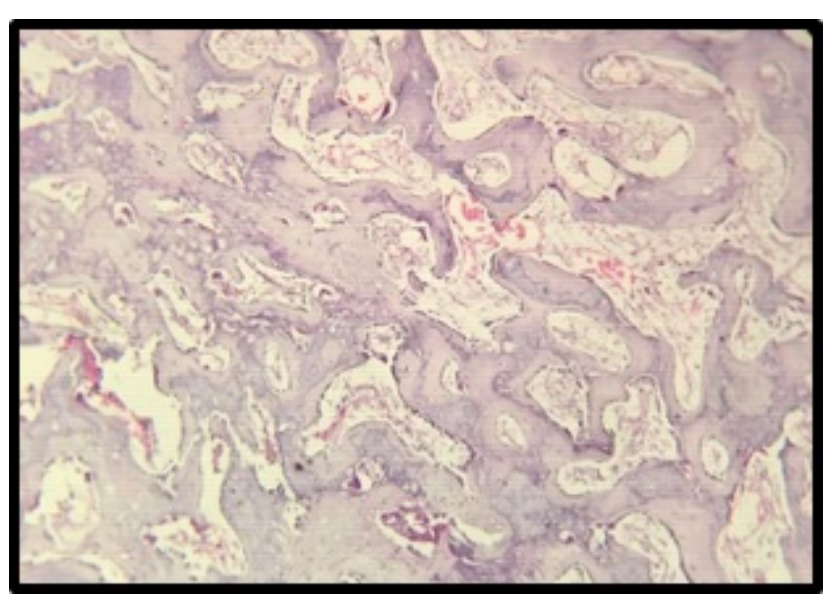

Figure 1. Benign mixed tumor. Well differentiated bone component of benign mixed tumor [HE; 10x].

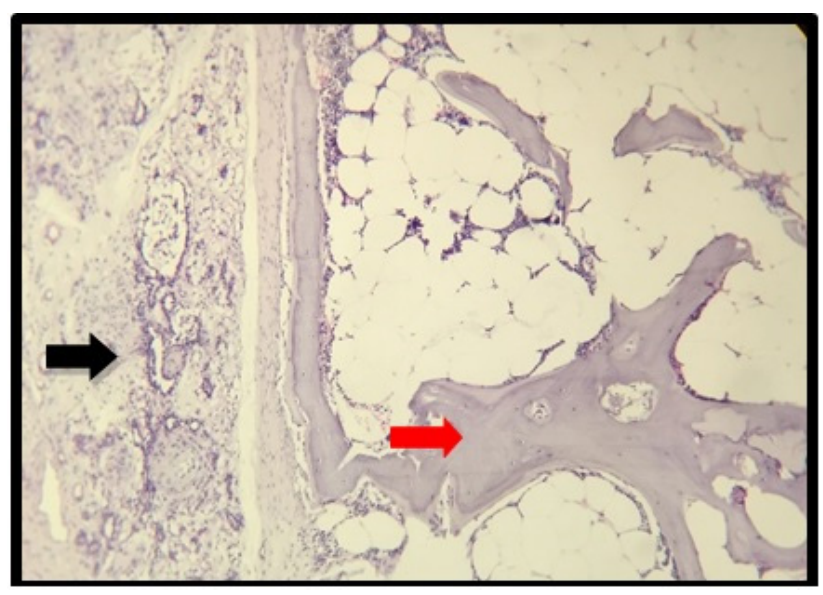

Figure 2. Carcinoma in mixed tumor. On the left (black arrow) there are epithelial cells arranged in tubules. On the right (red arrow) well differentiated bone tissue associated with bone marrow formation [HE; 10x]. 


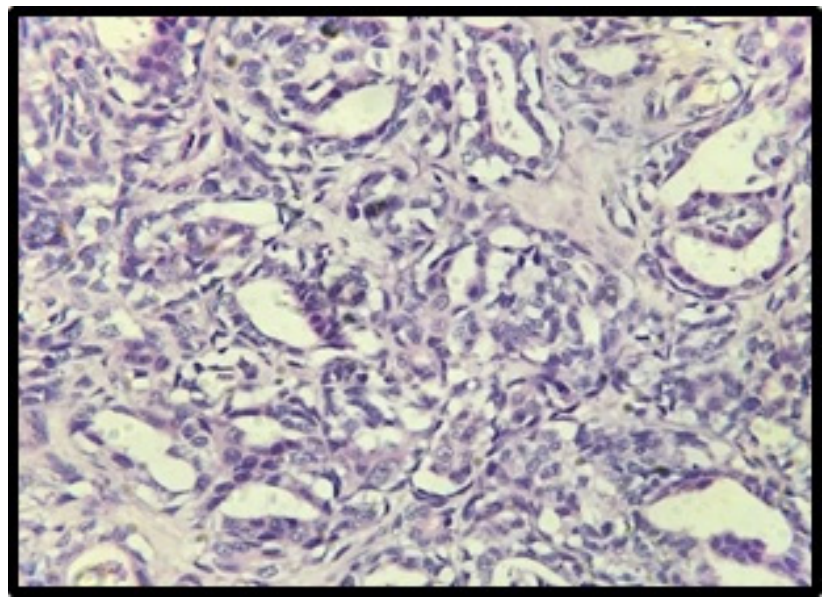

Figure 3. Tubular carcinoma. Epithelial cell proliferation in tubular arrangement. Note the absence of myoepithelial cells and basement membrane [HE; 40x].

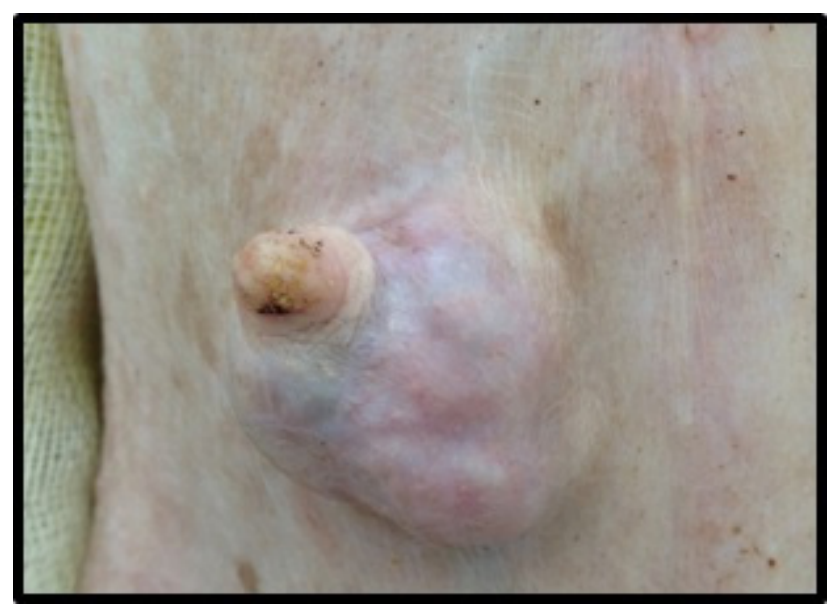

Figure 4. Unbred female (SRD), with a $3 \mathrm{~cm}$ nodule in the right caudal abdominal breast, with histopathological classification of carcinoma in mixed tumor.

Regarding the macroscopic characteristics of the 47 nodules (Figures 4 and 5), 19 (40.4\%) were smaller than $3 \mathrm{~cm}, 14(29.8 \%)$ were between 3 and 5 $\mathrm{cm}, 14(29.8 \%)$ were larger than $5 \mathrm{~cm}$, and three (6.4\%) presented ulceration area (Table 3 ).

Almost 64\% (23/36) of the evaluated malignant nodules were equal to or larger than $3 \mathrm{~cm}$, and more than half of which $(13 / 23)$ were larger than $5 \mathrm{~cm}$. In contrast, more than $70 \%(8 / 11)$ of the benign nodules were smaller than $3 \mathrm{~cm}$ (Table 3). Statistical analysis of the clinical findings revealed that there was a significant correlation between the $(P<0.05)$ size of the breast lump and the character of the neoplasm (Table 3 ), and tumors larger than $5 \mathrm{~cm}$ were associated with malignancy when compared to the same or smaller than $3 \mathrm{~cm}$.

Regarding ultrasound findings (Figures 6 to 9), heterogeneous echotexture and mixed tumor component were associated with malignancy (Table 4). Another ultrasound finding that was associated with malignancy of mammary neoplasms was the presence of the mixed component, which was characterized by the existence of both solid and cystic areas in the same nodule [9].

One nodule with benign histopathological classification and one classified as malignant were not visualized during breast ultrasound. These nodules were measured during the clinical evaluation of the patients and both presented with a diameter close to or less than one centimeter.

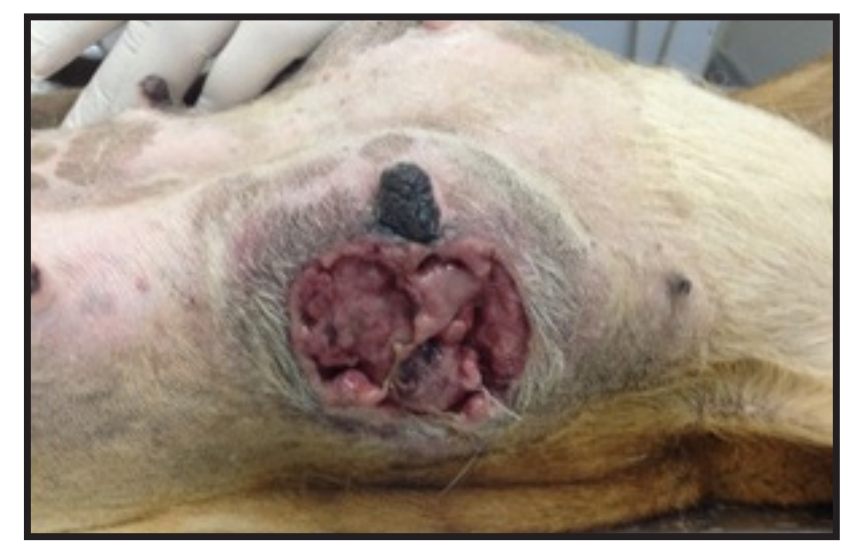

Figure 5. Unbred $\operatorname{dog}(\mathrm{SRD})$, with a $9 \mathrm{~cm}$ nodule in the left caudal thoracic breast, ulcerated, with histopathological classification of carcinoma in mixed tumor.

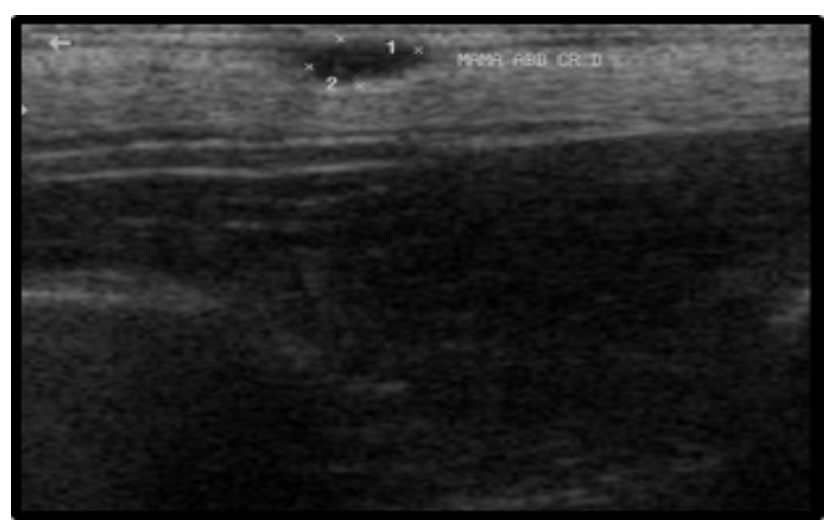

Figure 6. Ultrasound image of a nodule that is histopathologically classified as carcinoma in mixed tumor. An ovoid structure interspersed in the parenchyma, measuring $0.53 \mathrm{~cm} \times 0.27 \mathrm{~cm}$, hypoechogenic solid pattern with irregular margins.

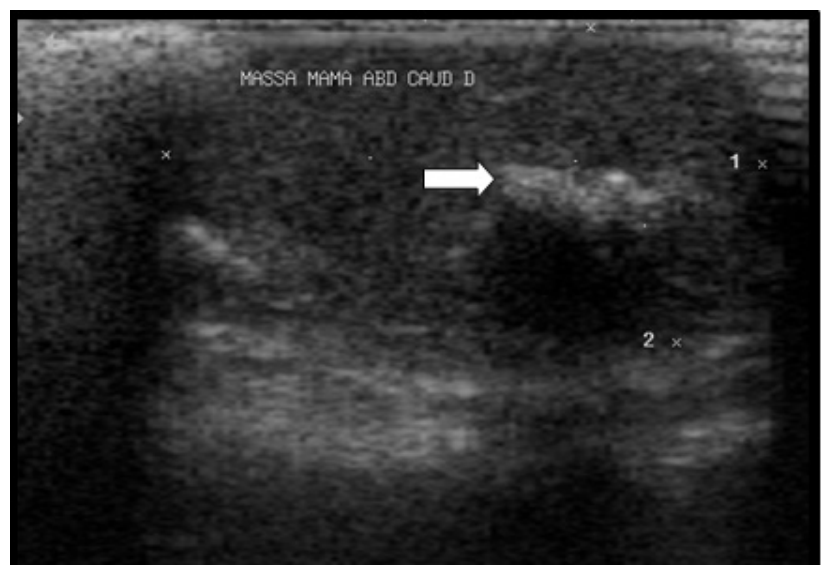

Figure 7. Ultrasound image of nodule histopathologically classified as carcinoma in mixed tumor. Note a mass measuring $2.89 \mathrm{~cm} \times 1.56 \mathrm{~cm}$, solid pattern, heterogeneous hypoechogenic, with interspersed amorphous hyperechogenic area, forming posterior acoustic shading (arrow). 
P.E.B. Guedes, H.B.T. Daniel, K.M.O.R. Sampaio, et al. 2020. Clinical and Ultrasonographic Aspects of Benign and Malignant

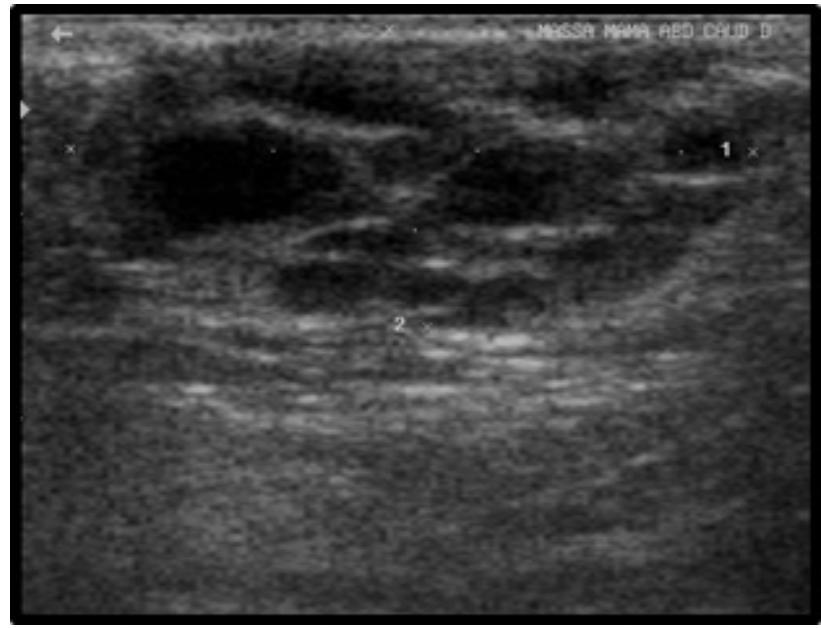

Figure 8. Ultrasound image of nodule histopathologically classified as ductal carcinoma. An ovoid structure with irregular margins, measuring $3.75 \mathrm{~cm} \times 1.58 \mathrm{~cm}$, with an angiogenic multicavity pattern, with internal septations is noted.

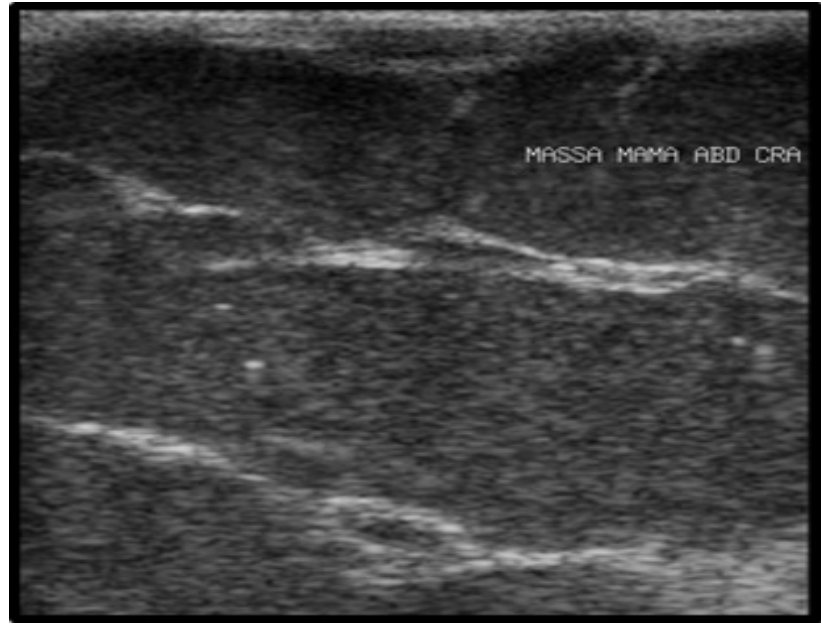

Figure 9. Ultrasound image of breast cancer histopathologically classified as papillary carcinoma. An extensive hypoechogenic mass of mixed pattern, predominantly liquid, densely particulate, with irregular margins and internal septations is noted.

Table 3. Clinical findings of benign and malignant nodules evaluated in dogs with mammary neoplasms.

\begin{tabular}{|c|c|c|c|c|c|}
\hline & Histopathological classification & & $\begin{array}{l}\text { Benign } \\
(\mathrm{n}=11)\end{array}$ & $\begin{array}{c}\text { Malignant } \\
(\mathrm{n}=36)\end{array}$ & $P$ value \\
\hline & \multirow{3}{*}{ Size } & $<3 \mathrm{~cm}$ & $08(72.7 \%)$ & $11(30.6 \%)$ & \multirow{3}{*}{0.05} \\
\hline \multirow{6}{*}{ Clinical findings } & & $\geq 3 \mathrm{e} \leq 5 \mathrm{~cm}$ & $03(27.3 \%)$ & $11(30.6 \%)$ & \\
\hline & & $>5 \mathrm{~cm}$ & 0 & $14(38.8 \%)$ & \\
\hline & \multirow{2}{*}{ Adherence to adjacente tissues } & Yes & $05(45.5 \%)$ & $17(47.2 \%)$ & \\
\hline & & No & $06(54.5 \%)$ & $19(52.8 \%)$ & ns \\
\hline & \multirow{2}{*}{ Ulceration } & Yes & 0 & $03(8.3 \%)$ & \\
\hline & & No & $11(100 \%)$ & $33(91.7 \%)$ & ns \\
\hline
\end{tabular}

Fisher tests; ns = not significant.

Table 4. Ultrasound findings of benign and malignant nodules evaluated in dogs with mammary neoplasms.

\begin{tabular}{|c|c|c|c|c|c|}
\hline \multicolumn{3}{|c|}{ Histopathological classification } & $\begin{array}{l}\text { Benign } \\
(\mathrm{n}=10)\end{array}$ & $\begin{array}{l}\text { Malignant } \\
(\mathrm{n}=35)\end{array}$ & $P$ value \\
\hline \multirow{9}{*}{$\begin{array}{l}\text { USG } \\
\text { findings }\end{array}$} & Shape & $\begin{array}{c}\text { Ovoid } \\
\text { Rounded } \\
\text { Elongated } \\
\text { Amorphous }\end{array}$ & $\begin{array}{c}09(90 \%) \\
01(10 \%) \\
0\end{array}$ & $\begin{array}{c}24(68.6 \%) \\
05(14.3 \%) \\
02(5.7 \%) \\
04(11.4 \%)\end{array}$ & ns \\
\hline & Boundaries & $\begin{array}{l}\text { Well-defined } \\
\text { Inaccurate }\end{array}$ & $\begin{array}{l}06(60 \%) \\
04(40 \%)\end{array}$ & $\begin{array}{l}20(57.1 \%) \\
15(42.9 \%)\end{array}$ & ns \\
\hline & Margins & $\begin{array}{l}\text { Regular } \\
\text { Irregular }\end{array}$ & $\begin{array}{l}09(90 \%) \\
01(10 \%)\end{array}$ & $\begin{array}{l}22(62.9 \%) \\
13(37.1 \%)\end{array}$ & ns \\
\hline & Echotexture & $\begin{array}{l}\text { Homogeneous } \\
\text { Heterogeneous }\end{array}$ & $\begin{array}{l}06(60 \%) \\
04(40 \%)\end{array}$ & $\begin{array}{l}06(17.1 \%) \\
29(82.9 \%)\end{array}$ & 0.05 \\
\hline & Echogenicity & $\begin{array}{l}\text { Hypoechoic } \\
\text { Hyperechoic }\end{array}$ & $\begin{array}{l}09(90 \%) \\
01(10 \%)\end{array}$ & $\begin{array}{l}33(94.3 \%) \\
02(5.7 \%)\end{array}$ & ns \\
\hline & Hyperechoic Halo & $\begin{array}{l}\text { Yes } \\
\text { No }\end{array}$ & $\begin{array}{l}01(10 \%) \\
09(90 \%)\end{array}$ & $\begin{array}{l}13(37.1 \%) \\
22(62.9 \%)\end{array}$ & ns \\
\hline & $\begin{array}{l}\text { Posterior acoustic } \\
\text { shading }\end{array}$ & $\begin{array}{l}\text { Yes } \\
\text { No }\end{array}$ & $\begin{array}{l}02(20 \%) \\
08(80 \%)\end{array}$ & $\begin{array}{l}04(11.4 \%) \\
31(88.6 \%)\end{array}$ & ns \\
\hline & Surrounding changes & $\begin{array}{l}\text { Yes } \\
\text { No }\end{array}$ & $\begin{array}{c}02(20 \%) \\
8(80 \%)\end{array}$ & $\begin{array}{l}15(42.9 \%) \\
20(57.1 \%)\end{array}$ & ns \\
\hline & Components & $\begin{array}{l}\text { Solid } \\
\text { Mixed }\end{array}$ & $\begin{array}{c}10(100 \%) \\
0\end{array}$ & $\begin{array}{l}23(65.7 \%) \\
12(34.3 \%)\end{array}$ & 0.05 \\
\hline
\end{tabular}




\section{DISCUSSION}

The age of most female dogs corroborates the reports in the literature, indicating that the breast cancer incidence increases with age, since it leads to a longer exposure to the carcinogenic initiators responsible for the mutations as well as promoters, such as hormonal changes $[8,16,21,28]$.

Epidemiological data, which revealed that $\mathrm{OSH}$ acted as a protective factor in female dogs without neoplasia, indicated that OSH continued to be a preventive measure to develop breast neoplasms even when performed later, since all the dogs were castrated after the second heat. This finding was in agreement with the results reported by Schneider et al. [25].

In addition, contraceptive use has been shown to be a risk factor for the development of breast tumors, corroborating studies by other researchers [16,21,28]. The lower incidence of breast cancer observed in other countries was due to the high rate of early castration, as in the United States [20]. Unfortunately, as evidenced in the present research, in Brazil the practice of contraceptive use overrides OSH as a contraceptive method.

However, with regard to the hormonal aspects, it is worth mentioning one of the cases followed during the execution of this work, which exemplifies the influence that exogenous hormones exert on the mammary tissue of the dogs. The youngest female dog included in this research, underwent progesterone-based contraceptive application a few months before developing the breast lump at the age of two. She presented with a $3 \mathrm{~cm}$ diameter breast tumor, located in the right caudal abdominal breast, whose histopathological classification was carcinoma in mixed tumor. This case reinforced the importance of early castration and public awareness of the indiscriminate use of contraceptives. OSH could have prevented the development of the breast lump at such an early age.

The high malignancy rate observed in the neoplasia samples of this study agrees with results obtained by other national researchers [28]. In addition, nearly $70 \%$ of the carcinomas were classified as carcinomas in mixed tumors, corroborated by the literature $[4,13]$, which indicated that in Brazil, this was the most commonly reported histopathological type of malignant mammary tumor. It is noteworthy that carcinoma in mixed tumor can start as a benign mixed tumor and progress to a malignant transformation of epithelial cells [4].

Regarding the histopathological grading, it was observed that, although malignant, most nodules presented with a low histopathological grading, since nearly $70 \%$ of the malignant tumors were classified as grade I, presenting a low mitotic index.

Regarding the time in which tutors delayed in providing veterinary care to the animals after tumor perception, the time of neoplasia progression was associated with the possibility of transforming a benign nodule into a malignant nodule [4]. As mentioned above, the epithelial component of benign neoplasms have the potential for a malignant transformation, possibly resulting in the formation of carcinomatous areas. This is due to the successive mutations in the neoplastic cells, which subsequently become more aggressive, with autonomous growth and insensitivity to growth inhibitory factors and tumor suppressor genes [15].

The breasts most affected by neoplasms in the dogs of this study were the caudal and inguinal abdominals. According to Lana et al. [16] the caudal inguinal and abdominal glands were primarily affected since they have more parenchymas, also corroborating the results previously obtained [21,28].

Regional lymphadenomegaly was diagnosed in more than $40 \%$ of the female dogs evaluated. Considering this, lymphadenomegaly may be associated with the presence of the breast lump [16] without necessarily indicating neoplastic dissemination, similar to the case of reactive hyperplasia, or possible owing to a primary or secondary inflammatory process [6]. This fact demonstrates the importance of a histopathological examination to distinguish between a non-neoplastic process and the metastatic spread of neoplasms, since the confirmation of metastasis influences the decision of postoperative therapy, as well as the prognosis of the disease.

Node size is one of the parameters evaluated to establish TNM. Tumor size evaluation is one of the most important factors to establish the prognosis of the animal $[3,11,12]$. Breast lumps with diameters greater than $5 \mathrm{~cm}$ were associated with a poorer prognosis and shorter survival time as compared to those with less than $5 \mathrm{~cm}$ [16].

Ultrasound findings suggested that the heterogeneous echotexture and mixed tumor component were associated with malignancy. Heterogeneous echotexture was interpreted as a variation of tumor echogenicity, justified by the diversity of tissue components in the nodule, including areas of tissue necrosis and circulatory changes such as hemorrhage, which are present in 
most malignant nodules $[2,19,26]$. In fact, most malignant nodules in this study with a heterogenous texture demonstrated areas of necrosis and/or inflammatory changes. Similarly, other authors $[19,26]$ also concluded that variation in echotexture was associated with malignant tumors. However, other authors have not observed a significant difference between benign and malignant tumors in relation to this parameter [30].

Regarding the mixed component, the association between this ultrasound parameter and malignant tumors was attributed to areas of necrosis and inflammation, which may lead to the emergence of solid and cystic areas with liquid content. The results associated with the mixed component was also evaluated by Feliciano et al. [10] who showed no significant difference in this parameter between benign and malignant neoplasms.

Additionally, in relation to tumors demonstrating which posterior shading, bone tissue formation was noted at histopathology, being classified as mixed, benign (one), or malignant (three) tumors. Here, this feature was not associated with malignancy, agreeing with other authors $[2,18]$.

Other ultrasound findings, such as shape, limits, margins, echogenicity, hyperechoic halo and surrounding changes, did not reveal significant association with the malignancy characteristics evaluated in this study. However, other authors have associated the parameters obtained by conventional ultrasound with benign neoplasms, such as regular and welldefined margins, homogeneous echogenicity, absence of changes in surrounding tissue, well-defined limits, and oval or ellipsoid shape [2,9].

\section{CONCLUSION}

Therefore, contraceptive use increased the risk of breast lump development in female dogs, subsequently reduced via ovariohysterectomy, even when performed after the second heat. Given the regional cultural characteristics, it is clear that contraceptive use continues to overlap castration as a method to prevent estrus. Furthermore, the largest tumor diameter was associated with malignant neoplasms, which corresponded to most nodules evaluated here. Among these, mixed tumor carcinoma was the most common subtype. Summarily, in addition to the tumor diameter, echotexture and the type of tumor parenchymal component were ultrasonographic aspects indicative of the character of canine mammary neoplasms in this study, and that these findings have the perspective of being used as prognostic parameters for breast lumps in female dogs.

Acknowledgements. To CAPES, for the scholarship granted during the doctorate. To the professors Alexandre Dias Munhoz, Luci Ana Fernandes Martins, and Juneo Freitas Silva for their support and assistance in the research stages and to the students of Scientific Initiation Felipe Cesar da Silva Brazilian, Haissa Mabel Oliveira Vieira, Ana Gecica Souza Nunes, Anderson Vieira de Jesus and Mirian Brandão Jesus Silva, for helping to conduct clinical and laboratory evaluations of the biological samples obtained.

Ethical approval. The study was approved by the Animal Use Ethics Committee (CEUA-UESC), under protocol number $003 / 2015$.

Declaration of interest. The authors report no conflicts of interest. The authors alone are responsible for the content and writing of the paper.

\section{REFERENCES}

1 Bergman P.J. 2007. Paraneoplastic Syndromes. In: Withrow S.J. \& Macewen E.G. (Eds). Small Animal Clinical Oncology. 4th edn. Philadelphia: W.B. Saunders Co., pp.77-94.

2 Calas M.J.G., Koch H.A. \& Dutra M.V. 2007. Breast ultrasound: evaluation of echographic criteria for differentiation of breast lesions. Radiologia Brasileira. 40: 1-7.

3 Campos C.B. \& Lavalle G.E. 2017. Exame clínico. In: Cassali G.D. (Ed). Patologia Mamária Canina: do Diagnóstico ao Tratamento. São Paulo: Editora MedVet, pp.152-159.

4 Cassali G.D., Bertagnoli A.C., Ferreira E., Damasceno K.A., Gamba C.O.P \& Campos C.B. 2012. Canine Mammary Mixed Tumours: A Review. Veterinary Medicine International. 2012: 1-7. doi: 10.1155/2012/274608.

5 Cassali G.D., Lavalle G.E, Ferreira E., Estrela-Lima A., De Nardi A.B., Ghever C. \&Torres R. 2014. Consensus for the Diagnosis, Prognosis and Treatment of Canine Mammary Tumors - 2013. Brazilian Journal of Veterinary Pathology. 7(2): 38-69. 
6 Day M.J. 2004. Differential Diagnosis of Lymphadenopathy. In: Proceedings of the 29th Word Small Animal Veterinary Association World Congress - WSAVA (Rhodes, Greece). pp.1-4.

7 Engelking L.R. 2010. Glândulas Mamárias. In: Engelking L.R. (Ed). Fisiologia Endócrina e Metabólica em Medicina Veterinária. 2.ed. São Paulo: Roca, pp.44-49.

8 Egenvall A., Bonnett B. N., Ohagën P., Olsson P., Hedhammar A. \& Von Euler H. 2005. Incidence of and survival after mammary tumors in a population of over 80,000 insured female dogs in Sweden from 1995 to 2002. Preventive Veterinary Medicine. 69: 109-127.

9 Feliciano M.A.R., Vicente W.R.R., Leite C.A.L. \& Silveira T. 2008. Abordagem ultrassonográfica da neoplasia mamária em cadelas: revisão de literature. Revista Brasileira de Reprodução Animal. 32(3): 197-201.

10 Feliciano M.A.R., Uscategui R.A.R., Maronezi M.C., Simões A.P.R., Silva P., Gasser B. \& Vicente W.R.R. 2017. Ultrasonography methods for predicting malignancy in canine mammary tumors. PLOS One. 22: 1-14.

11 Ferreira E., Bertagnolli A.C., Cavalcanti M.F., Schmitt F.C. \& Cassali G.D. 2009. The relationship between tumour size and expression of prognostic markers in benign and malignant canine mammary tumours. Veterinary and Comparative Oncology. 7(4): 230-235.

12 Ferreira E., Campos M.R.A., Nakagaki K.Y.R. \& Cassali G.D. 2017. Marcadores prognósticos e preditivos no câncer de mama. In: Cassali G.D. (Ed). Patologia Mamária Canina: do Diagnóstico ao Tratamento. São Paulo: Editora MedVet, pp.141-149.

13 Gamba C.O., Ferreira E., Salgado B.S., Damasceno K.A., Bertagnolli A.C., Nakagaki K.Y.R. \& Cassali G.D. 2017. Neoplasias malignas. In: Cassali G.D. (Ed). Patologia Mamária Canina: do Diagnóstico ao Tratamento. São Paulo: Editora MedVet, pp.91-116.

14 Gasser B., Rodriguez M.G.K., Uscategui R.A.R., Silva P.A., Maronezi M.C., Pavan L., Feliciano M.A.R. \& Vicente W.R.R. 2018. Ultrasonographic characteristics of benign mammary lesions in bitches. Veterinarni Medicina. 63(5): 216-224.

15 Hanahan D. \& Weinber R.A. 2000. The Hallmarks of Cancer. Cell. 100: 57-70.

16 Lana S.E., Rutteman G.R. \& Withrow S.T. 2007. Tumors of Mammary Gland. In: Withrow S.J. \& Macewen E.G. (Eds). Small Animal Clinical Oncology. 4th edn. Philadelphia: W.B. Saunders Co., pp.619-636.

17 Misdorp W. 2002. Tumors of the mammary gland. In: Meuten D.J. (Ed). Tumors in Domestic Animals. 4th edn. Ames: Iowa State Press, pp.575-606.

18 Mahmoud S.M.A., Paish E.C., Powe D.G., Macmillan R.D., Grainge M.J., Lee A.H.S., Ellis I.O. \& Green A.R. 2011. Tumor-Infiltrating CD8+ Lymphocytes Predict Clinical Outcome in Breast Cancer. Journal of Clinical Oncology. 29: 1949-1955.

19 Nyman H.T., Nielsen O.L., Mcevoy F.J., Lee M.H., Martinussen T., Hellmen E. \& Kristensen A.T. 2006. Comparison of B-mode and Doppler ultrasonographic findings with histologic features of benign and malignant mammary tumors in dogs. American Veterinary Medical Association. 67(6): 985-991.

20 Nunes F.C., Campos C.B. \& Bertagnolli A.C. 2017. Aspectos Epidemiológicos das Neoplasias Mamárias Caninas. In: Cassali G.D. (Ed). Patologia Mamária Canina: do Diagnóstico ao Tratamento. São Paulo, Editora MedVet, pp.27-32.

21 Oliveira L.O., Oliveira R.T., Loretti A.P., Rodrigues R. \& Driemeier D. 2003. Aspectos epidemiológicos da neoplasia mamária canina. Acta Scientiae Veterinariae. 31: 105-110.

22 Owen L.N. 1980. TNM Classification of Tumors in Domestic Animal. Geneva: World Health Organization, 53p.

23 Piculo F., Marini G., Damasceno D.C., Sinzato Y.K., Barbosa A.M.P., Matheus S.M.M. \& Rodrigues G. 2014. Metodologia e equipamentos. In: Guia ilustrado da morfologia do tecido uretral de ratas [online]. São Paulo: Editora UNESP, pp.13-26.

24 Queiroga F.L. \& Lopes C. 2002. Tumores mamários caninos - Novas perspectivas. In: Anais do Congresso de Ciências Veterinárias (Oeiras, Portugal). pp.183-190.

25 Schneider R., Dorn C.R. \& Aylor D.O.N. 1969. Factors Influencing Canine Mammary Cancer Development and Postsurgical Survival. Journal of the National Cancer Institute. 43(6): 1249-1261.

26 Soler M., Dominguez E., Lucas X., Novellas R., Gomes-Coelho K.V., Espada Y. \& Agut A. 2016. Comparison between ultrasonographic findings of benign and malignant canine mammary gland tumours using B-mode, colour Doppler, power Doppler and spectral Doppler. Research in Veterinary Science. 107: 141-146.

27 Sorenmo K.U. 2003. Canine mammary gland tumors. Veterinary Clinical Small Animal. 33: 573-596. 
28 Toríbio J.M.M.L., Estrela-Lima A., Martins Filho E.F., Ribeiro L.G.R.R., D’assis M.J.M.H., Teixeira R.G. \& Costa Neto J.M. 2012. Caracterização clínica, diagnóstico histopatológico e distribuição geográfica das neoplasias mamárias em cadelas de Salvador, Bahia. Revista Ceres. 59(4): 427-433.

29 Valle G.R. 2017. Aspectos fisiológicos e fisiopatológicos em cadelas. In: Cassali G.D. (Ed). Patologia Mamária Canina: do Diagnóstico ao Tratamento. São Paulo: Editora MedVet, pp.16-26.

30 Vannozzi I., Tesi M., Zangheri M., Innocenti V.M., Rota A., Citi S. \& Poli A. 2018. B-mode ultrasound examination of canine mammary gland neoplastic lesions of small size (diameter $<2 \mathrm{~cm}$ ). Veterinary Research Communications. 42: $137-143$. 